\title{
Detection of herpes simplex virus type 1,2 and varicella zoster virus DNA in recipient corneal buttons
}

\author{
B Elske van Gelderen, Allegonda Van der Lelij, W Frits Treffers, Ruth van der Gaag
}

\begin{abstract}
Aim-To study the value of polymerase chain reaction (PCR) analysis, to detect viral DNA in recipient corneal buttons taken at the time of penetrating keratoplasty (PKP) in patients with an initial diagnosis of herpetic stromal keratitis (HSK). Since HSK has a tendency to recur, an accurate diagnosis of previous HSK could be the reason to start antiviral treatment immediately, thereby possibly decreasing the number of graft failures due to recurrent herpetic keratitis.

Methods-Recipient corneal buttons and aqueous humour (AH) samples were obtained at the time of PKP from HSK patients $(n=31)$ and from other patients $(n=78)$. Eye bank corneas were also used $(n=23)$. Herpes simplex virus type 1 (HSV-1), type 2 (HSV-2), and varicella zoster virus (VZV) infection were assessed by PCR and antibody detection.

Results-The clinical diagnosis HSK could be confirmed by PCR for HSV-1 in $10 / 31(32 \%)$. In these corneal buttons HSV-2 DNA was detected in 1/31 (3\%) and VZV DNA in 6/31 (19\%). Intraocular antiHSV antibody production was detected in 9/28 AH samples tested (32\%). In the other patient derived corneas HSV-1 DNA was detected in $13 / 78(17 \%)$, including eight failed corneal grafts without clinically obvious herpetic keratitis in the medical history. In clear eye bank corneas HSV-1 was detected in $1 / 23(4 \%)$.

Conclusions-PCR of HSV-1 on corneal buttons can be a useful diagnostic tool in addition to detection of intraocular antiHSV antibody production. Furthermore, the results were suggestive for the involvement of corneal HSV infection during allograft failure of corneas without previous clinical characteristic signs of herpetic keratitis.
\end{abstract}

(Br f Ophthalmol 2000;84:1238-1243)

Deep corneal scar formation is one of the reasons for performing penetrating keratoplasty (PKP). ${ }^{12}$ Corneal scars can result from trauma, chemical injury, or corneal ulceration due to pathogenic viruses, bacteria or (other) parasites. ${ }^{12}$ Obviously, more than one factor can affect the clarity of the cornea or corneal graft at the same time, including corneal graft rejection. Herpes simplex virus (HSV) infection of the corneal stroma is the most prominent cause of scar formation, impairing visual acuity. ${ }^{3}$

After invading the cornea, herpes viruses can establish latency in the trigeminal ganglion ${ }^{4}$ and can be reactivated by stimuli such as sunlight, fever, or severe emotional stress ${ }^{5}$ to cause recurrences of ocular disease. HSV infection of corneal grafts could be explained by these HSV recurrences from the sensory ganglion ${ }^{6}$ or, less frequently, by newly acquired corneal HSV infection. ${ }^{7}$ This could be acquired by transmission via the donor cornea ${ }^{8-12}$ or by infection from the external environment. ${ }^{7}$ Ocular infection with herpes virus may be facilitated by treatment with local corticosteroids for prolonged periods of time. Intraocular HSV infection can be diagnosed by clinical manifestations, reaction to antiviral treatment, or by means of invasive methods. Aqueous humour $(\mathrm{AH})$, obtained by paracentesis of the anterior chamber of the eye can be examined for the presence of antiherpetic antibodies and by polymerase chain reaction (PCR) techniques to detect viral DNA fragments. ${ }^{13}$ Histological examination of all three layers of the cornea is possible after PKP since corneal tissue is excised during PKP. This procedure makes it possible to examine the corneal tissue itself.

Herpetic stromal keratitis (HSK) is thought to be initiated by HSV-1. ${ }^{14-17} \mathrm{HSV}-1$ has been detected in corneas during active and quiescent phases during and after corneal HSV related disease. ${ }^{15}{ }^{18}$ The roles of HSV-2, usually transmitted by direct sexual contact, ${ }^{5}$ and varicella zoster virus (VZV) ${ }^{18-20}$ were less frequently involved in the aetiology of herpetic keratitis than HSV-1. ${ }^{14} 19^{21}$ In this study, a series of recipient corneal buttons, including regrafts, obtained at the time of corneal transplantation, were analysed for the presence of HSV-1, HSV-2, and VZV DNA by PCR.

\section{Materials and methods}

PATIENTS AND CONTROLS

This study was approved by the medical ethics committee of the University Medical Centre of Utrecht, Netherlands. The study confirms adherence to the Declaration of Helsinki. Informed consent was obtained from all the patients. Consecutive PKPs were performed in the University Medical Centre, Netherlands $(n=328)$, between 1995 and 1997; corneas and AH samples from 109 PKPs were included in this study. All patients with a previous history of HSK were selected $(n=31)$. These patients had corneal opacification after HSK, which was based on ocular examinations and clinical 
Table 1 PCR methods

\begin{tabular}{lllll}
\hline PCR for & Primer pair & {$\left[\mathrm{Mg}^{2+}\right](M)$} & $\begin{array}{l}\text { Annealing } \\
\text { temperature }\end{array}$ & $\begin{array}{l}\text { Product size (base } \\
\text { pairs) }\end{array}$ \\
\hline HSV-1 & TK1, TK2 & 0.002 & 60 & 507 \\
& TK3, TK4 & 0.003 & 62 & 274 \\
HSV-2 & A, B & 0.002 & 66 & 397 \\
VZV & VZV1, VZV2 & 0.003 & 61 & 274 \\
& VZV3, VZV4 & 0.003 & 60 & 191 \\
\hline
\end{tabular}

history. In three patients intraocular anti-HSV antibody production had been detected before PKP, which had confirmed the clinical diagnosis. Additionally, corneas were obtained from all patients with an allograft failure without previous signs of herpetic keratitis $(n=17)$ and all patients with non-specified ulcers were selected $(n=9)$. Other corneas were obtained from patients without any previous clinical signs of ocular HSV infection. These were sex and age matched with HSK patients and PKPs were performed for the following diagnoses: keratoconus $(\mathrm{n}=15)$, bullous keratopathy (BKP) $(n=14)$, corneal dystrophies $(n=16)$, corneal trauma, including chemical burns $(\mathrm{n}=7)$.

An additional group of corneas was composed of 23 clear eye bank corneas (obtained 10-24 hours after death), which had been rejected for transplantation purposes because the endothelial cell count was just below 2300/ $\mathrm{mm}^{2}$. These donor corneas were kindly provided by the donor eye bank in the Netherlands Ophthalmic Research Institute, Amsterdam, Netherlands.

SAMPLES

Recipient corneas were removed during PKP, in transit for 7-24 hours, snap frozen upon delivery at the laboratory, and stored at $-70^{\circ} \mathrm{C}$. One quarter of the corneal button, including the scar tissue was used for total DNA extraction. DNA was isolated using the QIAamp Tissue Kit (Qiagen, West Sussex, UK). Purified total DNA samples were dissolved in 200 $\mu$ l of sterile TRIS-EDTA, pH 8 and visualised by electrophoresis on $0.7 \%$ agarose gel.

POLYMERASE CHAIN REACTION

Primers for HSV-1, HSV-2, and VZV DNA ${ }^{13} 15$ were selected from published sequences and checked for correctness by computer assisted analysis (BLAST searches on European Molecular Biology Laboratory (EMBL), GenBank databases). The primers for the thymidine kinase gene of HSV-1 appeared to be published incorrectly. The following primer sequences to detect HSV-1 DNA were used in this study:

TK-1: 5'-AAT-CGC-GAA-CAT-CTA-CACCAC-3'

TK-2: 5'-AAA-GCT-GTC-CCC-AAT-CCTCCC-3'

TK-3: 5'-CTG-CAG-ATA-CCG-CAC-CGTATT-3'

TK-4: 5'-CAT-CTT-CGA-CCG-CCA-TCCCAT-3'

The two primer sequences used for amplification of HSV-2 DNA were described by de Boer et al..$^{13}$

The primer sequences for VZV DNA were as follows:
VZV-1: 5'-AAT-GCC-GTG-ACC-ACCAAG-TAT-AAT-3'

VZV-2: 5'-TAC-GGG-TCT-TGC-CGGAGC-TGG-TAT-3'

VZV-3: 5'-TCC-ATC-TGT-CTT-TGT-CTTTCA-C-3

VZV-4: 5'-ATT-TTC-TGG-CTC-TAATCC-AAG-G-3'

All primer pairs were tested for the optimal $\mathrm{Mg}^{2+}$ concentration and annealing temperature (Table 1).

The amplification mixtures contained 100 ng of 3 ' and 5' primer (Eurogentec, Herstal, Belgium), $0.2 \mathrm{mM}$ of dATP, dCTP, dGTP, and dTTP (Pharmacia Biotech, Leiden, Netherlands), 1 unit of Taq polymerase (Perkin Elmer, NJ, USA), $2.5 \mu \mathrm{l}$ of template DNA solution, $\left[\mathrm{Mg}^{2+}\right]$ (Table 1), and PCR buffer, containing final concentrations of $0.15 \mathrm{M}$ $\left(\mathrm{NH}_{4}\right)_{2} \mathrm{SO}_{4}, 0.25 \mathrm{M} \mathrm{KCl}, 0.2 \mathrm{M} \mathrm{NaCl}, 0.1 \mathrm{M}$ TRIS.HCl, $20 \mathrm{mg} / \mathrm{ml}$ bovine serum albumin, $\mathrm{pH} 8.3$, and distilled water in a total volume of $25 \mu \mathrm{l}$, covered with mineral oil. One fifth of the first product was amplified using nested primers. The PCR was performed in a Biometra Trio-Thermoblock (Westburg, Leusden, Netherlands) as follows: the samples were denatured at $95^{\circ} \mathrm{C}$ for 5 minutes, 40 cycles of denaturation for 30 seconds $\left(95^{\circ} \mathrm{C}\right)$, primer annealing for 60 seconds at the optimal temperature, and elongation for 90 seconds (at $72^{\circ} \mathrm{C}$ ) were performed. After the last cycle, samples were incubated for 10 minutes at $72^{\circ} \mathrm{C}$ for additional elongation and stored at $4^{\circ} \mathrm{C}$.

The risk of contamination in the PCR was minimised by careful handling of all material, separate rooms for the three stages of PCR were used, dedicated pipettes with plugged tips were used, and guidelines of Kwok and Higuchi were followed. ${ }^{22}$ Negative controls samples were composed of sterile water and eye bank derived total cornea lysate. These samples were used in each round of DNA isolation and PCR analysis. Human fibroblasts infected with HSV-1 and HSV-2 strains, VZV, CMV, and CMV strain AD 169 isolated from patients were tested as positive controls (kindly provided by Dr Wertheim of the department of virology of the Academical Medical Centre in Amsterdam, Netherlands). Half of the final PCR product was run on $1.8 \%$ agarose gel in $0.5 \mathrm{X}$ TBE (45 mM TRIS, $50 \mathrm{mM}$ boric acid and $0.5 \mathrm{mM}$ EDTA, $\mathrm{pH}$ 8.3) containing ethidium bromide and photographed. The size of the various PCR products is listed in Table 1. After denaturation in $0.4 \mathrm{M} \mathrm{NaOH}$ for 20 minutes, the DNA was transferred to nylon membranes (Hybond-N, Amersham Life Science, Bucks) by Southern blot analysis in 10X SSC (1.5 M sodium chloride, $0.15 \mathrm{M}$ citric acid, $\mathrm{pH}$ 7) overnight. After ultraviolet cross linking (Stratagene UV) the blots were subjected to hybridisation with virus specific probes.

PCR amplification products of $\mathrm{HSV}-1$, HSV-2, and VZV were ligated into the pGEMTeasy vector (Promega, Madison, WI, USA) and used to transform Escherichia coli JM 109. Twenty transformants were subjected to PCR analysis with virus specific primers. For 
A

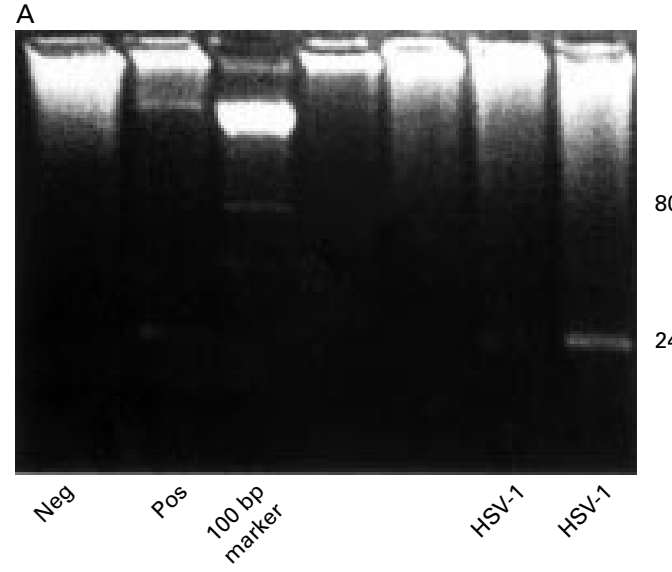

B

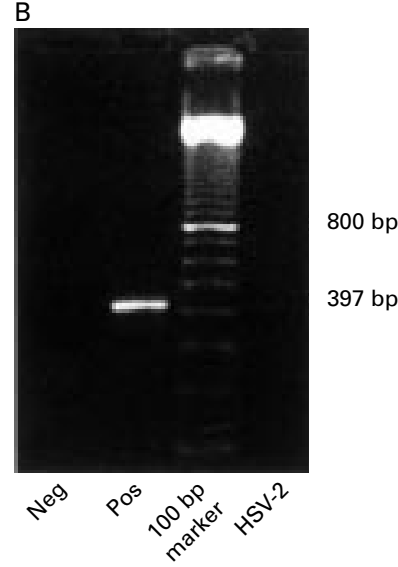

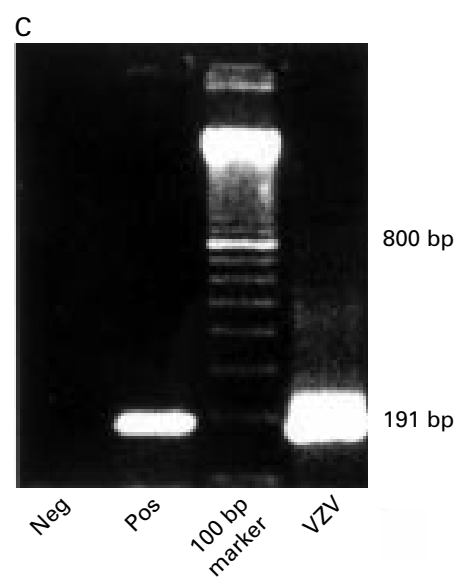

Figure 1 Electrophoresis gels of corneal DNA samples. The product sizes of the PCR for HSV-1, HSV-2, and VZV are indicated in (A), (B), and (C) respectively. $\mathrm{Neg}=$ negative control, Pos $=$ positive control (explained in Materials and methods).

each virus, DNA from overnight cultures of cloned inserts were isolated and purified using a DNA purification kit for electrophoresis (Qiagen, West Sussex, UK). The nucleotide sequence was checked for correctness by manual sequencing by the dideoxy method and computer assisted analysis (BLAST searches on EMBL, GenBank). Approximately $50 \mathrm{ng}$ of each insert was radioactively labelled with 20 $\mu \mathrm{Ci}\left[\alpha^{32} \mathrm{P}\right]$-dCTP $(3000 \mathrm{Ci} / \mathrm{mMol}), 1 \mathrm{mM}$ of each deoxythymidine triphosphate, deoxyguanosine triphosphate, deoxyadenosine triphosphate, $2 \mu \mathrm{l}$ hexanucleotides (Boehringer, Mannheim, Germany), and 2 units Klenow (Boehringer) at $37^{\circ} \mathrm{C}$ for 1 hour. This mixture was separated on a Sephadex column G-50 (Pharmacia, Sweden). Hybridisation of above mentioned Southern blots was performed overnight at $65^{\circ} \mathrm{C}$ in $6 \mathrm{X}$ SSC, $5 \mathrm{x}$ Denhardt's reagent, and $100 \mu \mathrm{g} / \mathrm{ml}$ sheared denatured herring sperm DNA. After hybridisation, filters were washed twice at $65^{\circ} \mathrm{C}$ in $0.2 \mathrm{X}$ SSC- $0.1 \%$ sodium dodecyl sulphate. Filters were exposed to $x$ ray film at $-70^{\circ} \mathrm{C}$ overnight.

The detection limits of each round of PCR were determined using known amounts of plasmid DNA, deduced from the optical density at $260 \mathrm{~nm}$, containing the HSV-1, HSV-2, or VZV specific fragments. In the nested HSV-1 DNA PCR $10^{2}$ of template copies could be detected, in the HSV-2 DNA PCR $10^{2}$ copies, and in the nested VZV DNA PCR $10^{2}$ of template copies could be detected. No cross reactivity between each of the primer sets and positive controls for HSV-1, HSV-2, VZV, or human DNA was observed.

INTRAOCULAR ANTI-HSV ANTIBODY PRODUCTION Antibody titres against HSV-1 and 2 and against $\mathrm{VZV}$ in $\mathrm{AH}$ and sera were assessed by means of commercially available ELISA plates (Gull, 's Hertogenbosch, Netherlands), according to the manufacturers' instructions. These were compared with the total immunoglobulin content in $\mathrm{AH}$ and serum by standard Mancini tests. This ELISA did not discriminate between HSV-1 or HSV-2. The Goldmann-Witmer coefficient (GWc), a measure for intraocular antibody production against HSV (1 and 2) and VZV was calculated. ${ }^{13}$ A GWc of greater than 3 was considered to be positive. ${ }^{13}$

\section{STATISTICAL ANALYSIS}

The results of the HSV-1 PCR were analysed using the $\chi$ quadrate $\left(\chi^{2}\right)$ statistics, to compare two groups with non-parametrical distributed data. The difference in time periods between the last episode of HSK to PKP in the group with positive PCR results for HSV-1 and negative PCR results for HSV-1 was analysed with the Mann-Whitney test. ${ }^{23}$

\section{Results}

In this study, corneal HSV infection was assessed in corneal tissue and in AH samples, obtained during PKP. In patients with a previous history of HSK, HSV-1 DNA was detected (Fig 1) in 10 out of 31 recipient corneal buttons (Table 2) and in five additional cases, a positive GWc for HSV was observed (Table 3). Therefore, the diagnosis of previous HSK could be confirmed in 15 out of 31 cases $(48 \%)$ with the combination of tests used in this study. The time that elapsed from the last clinical episode or recurrence of HSK until the moment of PKP was significantly shorter in the corneas in which HSV-1 was detectable (on average 30 months) than those negative for HSV-1 (on average 124 months, Fig 2).

In six corneal samples, the PCR for both HSV-1 and VZV were positive and one corneal sample yielded a positive PCR result for HSV-1, HSV-2 and VZV, indicated in Table 2.

Noteworthy was the large number of HSV-1 positive samples in failed corneal grafts and unspecified ulcers ( 11 out of $26,42 \%$ ), without a clinical history of HSK. The frequency of positive HSV-1 PCR results in this group $(n=26)$ was significantly higher compared with the other patient derived corneas $(n=52)$, $p=0.003$ (Table 2). The clinical signs that appeared during the process of graft failure had not been suggestive for herpetic keratitis and antiviral treatment had not been applied. In this group, HSV-1 DNA was detected in eight out of 17 corneal buttons (47\%), HSV-2 in none (0/17), and VZV in one out of 17 grafts 
Table 2 Detection of HSV-1, HSV-2, and VZV specific DNA fragments by PCR analysis on cornea derived DNA

\begin{tabular}{|c|c|c|c|c|c|}
\hline \multirow{2}{*}{\multicolumn{2}{|c|}{ Diagnosis at PKP }} & \multirow[b]{2}{*}{ No } & $H S V-1$ & $H S V-2$ & $V Z V$ \\
\hline & & & \multicolumn{3}{|c|}{ (positive results) } \\
\hline \multirow[t]{2}{*}{ I } & HSK, primary graft & 20 & 8 & 0 & $5^{\star}$ \\
\hline & Allograft failure with initial HSK diagnosis & 11 & 2 & 1 & $1 \dagger$ \\
\hline \multirow{2}{*}{ II } & Allograft failure with initial non-HSK diagnosis & 17 & 8 & 0 & $1 \ddagger$ \\
\hline & Ulcers, non-specified & 9 & 3 & 0 & $1 \neq$ \\
\hline \multirow[t]{4}{*}{ III } & Keratoconus & 15 & 0 & 0 & 2 \\
\hline & $\mathrm{BKP}$ & 14 & 2 & 0 & $2 \ddagger$ \\
\hline & Corneal dystrophies & 16 & 0 & 0 & 1 \\
\hline & Corneal trauma, including chemical burns & 7 & 0 & 0 & 1 \\
\hline IV & Eye bank corneas & 23 & 1 & 0 & 0 \\
\hline
\end{tabular}

Statistical analysis $\left(\chi^{2}\right)$ showed significant differences in the amount of positive results (HSV-1 PCR) when group I was compared with IV, $p=0.012$ and group II was compared with III, $p=0.003$, and II compared with IV, $p=0.003$.

*Three dual infections and two single VZV infections; †triple infection; łdual infections.

Table 3 HSV-1 antibodies and HSV-1 DNA in aqueous humour at the time of perforating keratoplasty

\begin{tabular}{|c|c|c|c|c|c|c|}
\hline \multirow{3}{*}{$\frac{\text { Diagnosis at } P K P(n)}{\text { HSK, primary graft (20) }}$} & \multirow{2}{*}{\multicolumn{2}{|c|}{$\begin{array}{l}\text { PCR HSV-1 in } \\
\text { corneal button }\end{array}$}} & \multicolumn{2}{|c|}{$\begin{array}{l}\text { PCR HSV-1 in * } \\
\text { aqueous humour }\end{array}$} & \multicolumn{2}{|c|}{$\begin{array}{l}\text { Intraocular anti HSV† } \neq \\
\text { antibody production }\end{array}$} \\
\hline & & & \multirow{2}{*}{$\begin{array}{l}\text { positive: } \\
0\end{array}$} & \multirow{2}{*}{$\frac{\text { negative: }}{6}$} & \multirow{2}{*}{$\begin{array}{l}\text { positive: } \\
4\end{array}$} & \multirow{2}{*}{$\begin{array}{c}\text { negative: } \\
4\end{array}$} \\
\hline & positive: & 8 & & & & \\
\hline \multirow{3}{*}{ Allograft failure with initial HSK diagnosis (11) } & negative: & 12 & 0 & 12 & $1 \ddagger$ & 11 \\
\hline & positive: & 2 & 0 & 2 & 0 & 2 \\
\hline & negative: & 9 & 0 & 7 & 4 & 2 \\
\hline \multirow[t]{2}{*}{ Allograft failure with initial non-HSK diagnosis (17) } & positive: & 8 & 0 & 6 & $2 \ddagger$ & 2 \\
\hline & negative: & 9 & 0 & 8 & 1 & 4 \\
\hline \multirow[t]{2}{*}{ Ulcers, non-specified (9) } & positive: & 3 & 0 & 3 & 0 & 2 \\
\hline & negative: & 6 & 0 & 6 & 0 & 3 \\
\hline \multirow[t]{2}{*}{ Other diagnosis, non-HSK (52) } & positive: & 2 & 0 & 1 & 0 & 1 \\
\hline & negative: & 50 & 0 & 3 & 0 & 3 \\
\hline
\end{tabular}

*In a great number of cases, the amount of AH was insufficient to detect antibody production and perform PCR; †the ELISA did not discriminate between HSV-1 and HSV-2; †in 1 case the GWc for VZV was also positive.

$(6 \%)$. In corneas with healed non-specified ulcers, in which a bacterial or neurotrophic cause was presumed, HSV-1 DNA was present in three out of nine corneal buttons $(33 \%)$ and VZV DNA in one out of nine $(11 \%)$.

In the recipient corneal buttons of the other patient groups, without any previous clinical HSV related ophthalmological symptoms $(n=52)$, only two corneas seemed to be infected with HSV-1, as well as with VZV. In four other corneas the PCR for VZV was positive.

Eye bank corneas without visible scars were provided for investigation after the endothelial cell count had been determined and found insufficient for transplantation purposes. These corneas were clear and non-diseased,

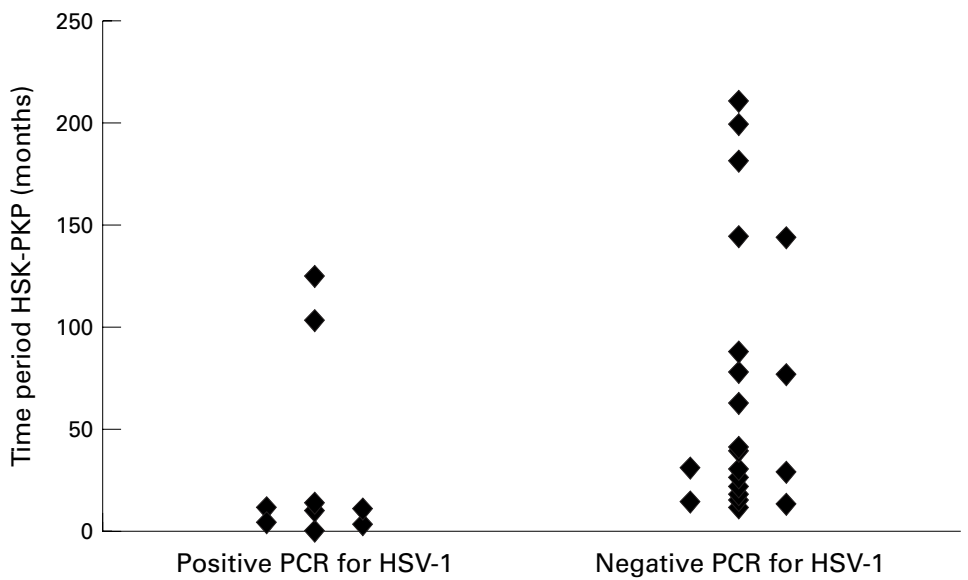

Figure 2 Cases with positive PCR results in the PCR for HSV-1 had significantly shorter time periods between the last episode of HSK and PKP then cases with negative PCRs (Mann-Whitney test, $p=0.004$ ). The median time period was 10 months (range $1-125$ months) with positive HSV-1 PCRs and 41 months (range 11-210 months) with negative PCR results.
HSV-1 DNA was detected in only one out of 23 DNA samples. The number of positive results in the HSV-1 PCR in the group with previous HSK $(n=31)$ was significant compared with eye bank derived corneas $(n=23)$, $\mathrm{p}=0.012$ (Table 2).

In Table 3, additional results of herpes virus PCR analysis and anti-HSV antibody production in $\mathrm{AH}$ samples obtained at the time of PKP, are presented. It appeared that the PCR for HSV-1 remained negative in all $\mathrm{AH}$ samples; whereas antibody production against HSV was detected in 12 samples, including nine from patients with a history of HSK or allograft failure. In case of a negative PCR for HSV-1 in the corneal button, anti-HSV-1 antibody production in $\mathrm{AH}$ was of additional value for the confirmation of the diagnosis of previous HSK. Anti-HSV antibody production in $\mathrm{AH}$ could not be observed in any of the patients with corneal ulcers of non-HSK related disease.

\section{Discussion}

Intraocular HSV-1 infection could be confirmed in 15 out of 31 patients with a clinical history of HSK (48\%). A positive test result in the HSV-1 PCR was obtained in 10 out of 31 cornea samples and anti-HSV antibody production in $\mathrm{AH}$ was detectable in five additional cases.

In this study, primers for the thymidine kinase gene of HSV-1 were applied and in 10 out of $31(32 \%)$ of the HSK patients, HSV-1 was detected in the recipient corneas. The same primers were reported to yield a positive result in eight out of 11 corneal DNA samples $(73 \%) .{ }^{15}$ The number of corneal buttons tested 
in our study ( $n=31)$ was, however, larger and the time period from the last HSK recurrence until PKP, which will undoubtedly have affected the number of positive cases, was not mentioned in the study of Cantin..$^{15}$ The choice of which DNA fragment of the HSV-1 genome is to be multiplied influences the sensitivity of the PCR. Other parts of the HSV-1 genome have also, although less frequently, been applied for the detection of HSV-1. The UL-42 gene was detected in 14 out of 47 samples $(30 \%),{ }^{14}$ the glycoprotein D gene in eight out of $18(44 \%)^{18}$, and a shared DNA-polymerase gene by HSV type 1 and type $2^{24}{ }^{25}$ in five out of eight $(63 \%){ }^{16}$

HSV can remain present in the cornea after HSK disease ${ }^{14-17}$ and some studies report the possibility of HSV latency in the cornea. ${ }^{17} 2627$ Withdrawal of the virus in the draining sensory trigeminal nerve is, however, more plausible with the lapse of time. ${ }^{46}$ The detection frequency of HSV-1 DNA decreased starting 6 months after experimental corneal HSV infection in rabbits. ${ }^{26}$ Similarly, in our study, HSV-1 DNA was found less frequently, with an increasing time interval from the last episode of HSK until sampling of the corneal button. Negative results in the PCR for HSV, in corneas derived from patients with a history of HSK may be explained by previous treatment with local and oral antiviral medication, inhibiting HSV, ${ }^{28}{ }^{29}$ or by a critically small number of HSV DNA copies in the test sample, below detection limits of the PCR assay.

In patients with allograft failure without a history of HSK, an unexpected high number of HSV-1 positive recipient corneal buttons were found. In these patients, no antiviral treatment was used since no obvious clinical signs of corneal HSV infection had been observed during the process of graft failure. Some clinical expression forms of HSV induced corneal disease may be difficult to recognise. Furthermore, transmission of HSV through donor corneas can not be excluded. ${ }^{11}$

In systemically immunosuppressed patients, HSV infections appeared to occur more frequently. ${ }^{30}$ The application of local immunosuppressive eye drops may have a similar effect on corneal HSV infections. Besides the necessary application of local immunosuppression in recently cornea grafted eyes, the grafting procedure itself was identified as a stimulating factor for recurrences of corneal HSV infection. ${ }^{31}$ Local corticosteroids in the absence of antiviral medication, also increased the severity of intraocular HSV infection. ${ }^{31}$ In view of the difficulty of distinguishing herpes simplex infection from corneal allograft rejection and the great number of positive results for HSV in allograft failures without previous signs of herpetic keratitis in this study, it may be advisable to couple antiviral therapy with corticosteroid treatment in cases of an immunologically mediated corneal graft opacification process. ${ }^{2}$

The patients with non-specified ulcers (previously treated elsewhere) and positive PCR results for HSV-1 in the corneal button are illustrative of the need for more adequate diag- nostic procedures, at the time of corneal disease.

Positive results of HSV-1 in corneal DNA samples from patients without clinical herpetic keratitis in their medical history were unlikely to be the result of careless handling. ${ }^{22}$ In culture fluids and rims of healthy donor corneas HSV-1 DNA has been detected ${ }^{810}$ and a study reported transmission of corneal HSV infection to the recipient. ${ }^{9}$ Other explanatory factors for HSV-1 in control corneas may be subclinical HSV infection or the existence of less virulent virus strains. ${ }^{31}$

All PCRs for HSV-1 in AH samples remained negative, probably because all PKPs were performed during a quiescent phase of corneal disease. Viral DNA was detectable only shortly in an early phase of ocular HSV infection and anti-HSV antibody production for a prolonged period of time. ${ }^{13}$ In our study, antibody production against HSV was detected in nine cases with previous HSK, and in three cases of allograft failure without previous HSK. A positive test result in the GWc for HSV was found six times in cases with negative HSV-1 PCR results in the corneal button. Therefore, determination of the GWc for HSV in $\mathrm{AH}$ was of additional value in making the diagnosis of previous intraocular HSV infection.

HSV-2 and VZV were examined in the same corneal samples and VZV in the same $\mathrm{AH}$ samples. The PCR for HSV-2 was positive in two cases, one regraft with previous HSK and one cornea with BKP. HSV-2 has been detected in corneas with previous herpetic keratitis, ${ }^{24}$ but in other studies using PCR analysis HSV-2 could not be detected. ${ }^{14} 16$ HSV-2 is evidently capable of invading body sites outside the urogenital tract, which has been described earlier. ${ }^{5}$ Ocular VZV infection often coexists with HSV-1 infection, although keratitis with primary VZV infection has been reported. ${ }^{19}$ Recurrence of VZV infection often gives rise to pain and skin lesions in the affected dermatome. These signs were not observed in the patients with the few corneas in which the PCR for VZV was positive. The primer sequences for the three viruses were chosen carefully to avoid cross reactivity. Also, the possibility of contamination by handling of corneas and $\mathrm{AH}$ samples was minimised by careful handling during surgery, transport, and in the laboratory. ${ }^{22}$

In summary, at the time of PKP the diagnosis of previous corneal HSV infection can be made by PCR for HSV-1 on the corneal button and determination of antibody production against $\mathrm{HSV}$ in AH. Determination of the GWc for HSV in AH is of more value than performing PCR for $\mathrm{HSV}$ in $\mathrm{AH}$ at this stage. The results suggest herpetic keratitis can not only be caused by HSV-1 infections but might also be caused by infection with HSV-2 or mixed infections with HSV-1, HSV-2, and VZV. Furthermore, HSV DNA in the cornea and anti-HSV antibodies were present in a number of failed corneal grafts without previous signs of herpetic keratitis. Therefore, HSV-1 appeared to be involved in the process of irrevers- 
ible corneal allograft failure more often then expected based on clinical signs. The authors thank Dr Ron Peek for assistance with designing
the PCRs and critical reading of the manuscript. The authors the PCRs and critical reading of the manuscript. The authors
also thank the cornea bank of the Netherlands Ophthalmic also thank the cornea bank of the Netherlands Ophthalmic
Research Institute, Amsterdam and the Foundations EurotransResearch Institute, Amsterdam and the Foundations Eurotrans-
plant and Bio Implant Services, Leiden, Netherlands for plant and Bio Implant Services, Leiden, Netherlands for providing the human corneas.
supported this project financially.

1 Wilson SE, Kaufman HE. Graft failure after penetrating keratoplasty. Surv Ophthalmol 1986;34:325-56.

2 Larkin DFP. Corneal transplantation for herpes simplex keratitis. Br 7 Ophthalmol 1998;82:107-8.

3 Coster DJ. The Montgomery lecture. Some factors which affect the visual outcome of corneal transplantation. Eye 1991;5:265-78

4 Shimeld C, Whiteland JL, Nicholls SM, et al. Immune cell infiltration and persistence in the mouse trigeminal ganglion after infection of the cornea with herpes simplex virus type 1. F Neuroimmunol 1995;61:7-16.

5 Nahmias AJ, Roizman B. Infection with herpes simplex viruses 1 and 2. N Engl f Med 1973;289:667-74, 719-25, 781-9.

6 Sterk CC, Jager MJ, Swart-vd Berg M. Recurrent herpetic keratitis in penetrating keratoplasty. Doc Ophthalmol 1995; 20:29-33.

7 Remeijer L, Doornenbal P, Geerards AJM, et al. Newly acquired herpes simplex virus keratitis after penetrating keratoplasty Ophthalmog 1997 ;

8 Tullo AB, Marcyniuk B, Bonshek R, et al. Herpes virus in a donor cornea [Letter]. Eye 1990;4:766-7.

9 Cleator GM, Klapper PE, Dennett C, et al. Corneal donor infection by herpes simplex virus: herpes simplex virus DNA in donor corneas. Cornea 1994;13:294-304

10 Morris DJ, Cleator GM, Klapper PE, et al. Detection of herpes simplex virus DNA in donor cornea culture medium by polymerase chain reaction. $\mathrm{Br} \mathcal{F}$ Ophthalmol 1996;80:654-7.

11 Neufeld MV, Steinemann TL, Merin LM, et al. Identification of a herpes simplex virus-induced dendrite in an eyebank donor cornea. Cornea 1999;18:489-90.

12 Garweg JG, Boehnke M. Low rate of shedding of HSV-1 DNA, but not of infectious virus from human donor corneae into culture media. 7 Med Virol 1997;52:320-5.

13 Boer de JH, Verhagen C, Bruinenberg M, et al. Serologic and polymerase chain reaction analysis of intraocular fluids and polymerase chain reaction analysis of intraocular fluids in the diagnosis

14 Mietz H, Cassinotti P, Siegl G, et al. Detection of herpes simplex virus after penetrating keratoplasty by polymerase chain reaction: correlation of clinical and laboratory findings. Graefes Arch Clin Exp Ophthalmol 1995;233:71416. 15 Cantin EM, Chen J, McNeil J, et al. Detection of herpes
simplex virus DNA sequences in corneal transplant recipi- ents by polymerase chain reaction assays. Curr Eye Res 1991:10:15-21.

16 Holbach LM, Font RL, Baehr W, et al. HSV antigens and HSV DNA in avascular and vascularized lesions of human herpes simplex antigens. Curr Eye Res 1991;10:63-8.

17 Kaye SB, Lynas C, Patterson A, et al. Evidence for herpes simplex viral latency in the human cornea. Brf Ophthalmol 1991;75:195-200.

18 Garweg J, Böhnke M. Slow viral replication of HSV-1 is responsible for early recurrence of herpetic keratitis after corneal grafting. Cornea 1996;234:S133-8.

19 Power WJ, Hogan RN, Hu S, Foster CS. Primary varicellazoster keratitis: diagnosis by polymerase chain reaction. $\mathrm{Am}$ f Ophthalmol 1997;123:252-4.

20 Metcalf JF, Christianson MD, Brady A. Ocular inoculation of monkeys with simian varicella virus: clinical and histopathologic observations. Invest Ophthalmol Vis Sci 1995;36:41-51

21 Neumann-Haefelin D, Sundmacher R, Wochnik G, et al. Herpes simplex virus type 1 and 2 in ocular disease. Arch Ophthalmol 1978;96:64-9.

22 Kwok S, Higuchi R. Avoiding false positives with PCR. Nature 1989;339:237-8.

23 Schouten HJA. [Clinical statistics. A practical introduction in methodology and analysis]. Bohn Stafleu van Loghum, Houten/ Diegem 1995. Chapter 6. [Difference in averages between two groups]: 63-78 and Chapter 14. [Chi Quadrate]: 133-138. Dutch.

24 Cao M, Xiao X, Egbert B, et al. Rapid detection of cutaneous herpes simplex virus infection with the polymerase chain reaction. F Invest Dermatol 1989;82:391-2 .

25 Tsurumi T, Maeno K, Nishiyama Y. Nucleotide sequence of the DNA polymerase gene of herpes simplex virus type 2 and comparison with the type 1 counterpart. Gene 1987;52:129-37.

26 O'Brien WJ, Tsao L-S, Taylor JL. Tissue-specific accumulation of latency-associated transcripts in herpes virusinfected rabbits. Invest Ophthalmol Vis Sci. 1998;39:184753.

27 Zheng X, Marquart ME, Loustch JM, et al. HSV-1 migration in latently infected and naive rabbits after penetrating keratoplasty. Invest Ophthalmol Vis Sci 1999;40: $2490-7$.

28 The Herpetic Eye Disease Study Group. A Controlled trial of oral acyclovir for the prevention of stromal keratitis or iritis in patients with herpes simplex virus epithelial keratitis. The epithelial keratitis trial. Arch Ophthalmol 1997;115: 703-12.

29 Tambasco FP, Cohen EJ, Nguyen LH, et al. Oral acyclovir after penetrating keratoplasty for herpes simplex keratitis. Arch Ophthalmol 1999;117:445-9.

30 Bustamante CI, Wade JC. Herpes simplex virus infection in the immunocompromised cancer patient. I Clin Oncol 1991;9:1903-15.

31 Cook SD. Herpes simplex virus in the eye. Br F Ophthalmol 992;76:365-6. 